\title{
Keragaan Pengembangan Kuda Sandelwood di Wilayah Pasola Kabupaten Sumba Barat Daya
}

\author{
M. D. S. Randu, ${ }^{1, *}$ dan B. Hartono ${ }^{2}$ \\ ${ }^{1}$ Jurusan Peternakan, Politeknik Pertanian Negeri Kupang \\ ${ }^{2}$ Fakultas Peternakan, Universitas Brawijaya, Malang
}

\begin{abstract}
ABSTRAK
Penelitian bertujuan untuk mengetahui karakteristik peternak dan kondisi eksisting pengembangan kuda Sandelwood di wilayah Pasola Kabupaten Sumba Barat Daya. Penelitian menggunakan metode survey. Lokasi penelitian di Kecamatan Kodi, Kecamatan Kodi Bangedo, dan Kecamatan Kodi Balaghar ditentukan menggunakan teknik purposive sampling. Pengumpulan data dilakukan melalui wawancara mendalam terhadap 79 responden peternak kuda Sandelwood dengan berpedoman pada instrumen penelitian. Analisis data menggunakan statistik deskriptif. Hasil penelitian menunjukkan bahwa karakteristik peternak merupakan laki-laki berusia produktif dengan pengalaman beternak 21-30 tahun, jumlah kepemilikan ternak kuda di bawah 5 ekor, $35,44 \%$ berpendidikan tamat SD, dan 68,35\% tidak pernah mengikuti pelatihan teknis bidang peternakan. Kondisi eksisting aktivitas pengembangan kuda Sandelwood di wilayah Pasola Kabupaten Sumba Barat Daya dipengaruhi oleh terbatasnya modal, tata laksana pemeliharaan yang bersifat tradisional, rendahnya perhatian terhadap pemanfaatan produk (daging dan susu), dan kurangnya penerapan teknologi reproduksi, pakan, maupun limbah.
\end{abstract}

Kata kunci: Karakteristik peternak, Kondisi eksisting, Kuda Sandelwood, Pasola

\section{Development Performance of Sandalwood Horse in Pasola Areas of South-West Sumba Regency}

\section{ABSTRACT}

The research objectives were to evaluate farmer characteristics and existing conditions of Sandalwood horse development in Pasola areas at South-West of Sumba Regency. The research was conducted based on a survey method. The research location were Kodi, Kodi Bangedo, and Kodi Balaghar Districts, which were determined by using purposive sampling technique. Data collection were obtained by a depth-interviewing toward 79 respondents of the Sandalwood horse farmers based on the research instrument. The data were analyzed by applying descriptively statistic. The result shows that the farmer characteristics were men in productive age with 21-30 years period of experience in raising the horses, the amount of the horses were under 5, primary school graduated 35,44\% and 68,35\% have never followed technical training in livestock. The existing conditions of the Sandalwood horse development in the Pasola areas at South-West of Sumba Regency were influenced by some factors such as low capital, traditionally raising management, limitation attention towards the horse products (meat and milk), and low application of technologies in reproduction, feed, and waste aspects.

Keywords: Farmer characteristics, Existing conditions, Sandalwood horse, Pasola

\section{PENDAHULUAN}

Kuda Sandelwood atau sering disebut sebagai kuda Sandel merupakan sumber daya genetik (SDG) rumpun kuda lokal Indonesia yang dikembangkan di Provinsi Nusa Tenggara Timur (NTT) dengan wilayah sebaran asli geografis berada di Pulau Sumba (Ditjennak, 2014). Kuda Sandelwood berasal dari hasil persilangan antara kuda Arab dengan kuda poni lokal untuk memperbaiki penampilannya, dan dominan digunakan sebagai kuda pacu Indonesia (Detha et al., 2013). Sejarah perkembangan kuda Sandelwood di Pulau Sumba diawali pada abad ke-16 melalui perdagangan orang Eropa, yaitu pembelian hasil bumi berupa kayu cendana untuk ditukarkan dengan kuda maupun koin logam (Adams, 2004). Kuda Sandelwood banyak memberikan manfaat dalam kehidupan masyarakat Sumba baik secara ekonomi, sosial dan budaya, karena dominan digunakan sebagai sarana transportasi, sumber protein hewani, pertandingan

*Penulis Korespondensi: Melkianus D. S. Randu

Alamat: Jl. Prof. Dr. Herman Yohanes, Kupang, NTT 85011

E-mail: deddy_randu@yahoo.co.id ketangkasan, dan simbol kebudayaan tertinggi masyarakat (Randu, 2017a).

Sumba Barat Daya (SBD) merupakan satu diantara empat Kabupaten di Pulau Sumba Provinsi NTT yang memiliki potensi pengembangan kuda Sandelwood. Hal tersebut didukung oleh tersedianya lahan penggembalaan seluas $17.607 \mathrm{Ha}$, kebiasaan memelihara kuda Sandelwood secara turun-temurun, infrastruktur pendukung distribusi dan pemasaran, pasar hewan yang memudahkan perdagangan, harga jual dan permintaan yang tinggi dari Provinsi Sulawesi Selatan dan Nusa Tenggara Barat, keberadaan pemerintah dan swasta sebagai instrumen modal dan kebijakan, serta tersedianya kelompok tani sebagai pelaksana inovasi dan teknologi. Potensi lain ditunjukkan melalui peran kuda Sandelwood dalam kegiatan sosial budaya (Pasola, Mahar / Belis perkawinan, dan upacara kematian) sehingga menjadikan Kabupaten SBD sebagai destinasi pariwisata (Adams, 2004; Djawa, 2014; Nurrochsyam, 2011; Randu, 2017b).

Pasola merupakan salah satu ritual sosial budaya tahunan yang selalu dipertahankan dan dilaksanakan 
masyarakat di Kabupaten SBD sebagai ungkapan syukur atas hasil panen pertanian. Kegiatan tersebut dilakukan pada bulan Februari-Maret berdasarkan perhitungan kalender adat, dan menjadi perhatian wisatawan asing (foreign tourism) maupun domestik (domestic foreign tourism). Pasola diwujudkan melalui atraksi saling melempar lembing dari atas punggung kuda yang sedang dipacu oleh dua kelompok masyarakat yang berbeda (Nurrochsyam, 2011). Pasola dilaksanakan secara terpusat pada 3 dari 11 wilayah Kecamatan di Kabupaten SBD. Kuda Sandelwood dalam ritual Pasola tidak saja memiliki peran interaksi secara ekologi, namun telah menjadi bagian sosiologis dalam kehidupan budaya masyarakat Sumba.

Kuda Sandelwood yang dikembangkan di Kabupaten SBD saat ini mengalami beberapa permasalahan. Dinas Peternakan Kabupaten SBD (2016) melaporkan terjadinya penurunan populasi kuda sebesar 2,75\% selama tahun 2010-2014. Kondisi tersebut berbanding terbalik dengan kegiatan antar pulau ternak kuda yang meningkat 57,81\% tahun 20112015. Badan Pusat Statistik Kabupaten SBD (2017) melaporkan populasi kuda di wilayah Pasola, yaitu Kecamatan Kodi, Kodi Bangedo, dan Kodi Balaghar hanya memberikan kontribusi sebesar 2,67\%; 3,81\%; $4,00 \%$ terhadap total populasi kuda di Kabupaten SBD. Badan Pusat Statistik Provinsi NTT (2017) melaporkan populasi kuda di Pulau Sumba yang disumbangkan Kabupaten SBD memberikan kontribusi sebesar $10,51 \%$, lebih tinggi dibandingkan Kabupaten Sumba Barat $(9,82 \%)$, namun lebih rendah dibandingkan Kabupaten Sumba Tengah (18,47\%) dan Kabupaten Sumba Timur $(61,20 \%)$.

Permasalahan lain berkaitan dengan kebijakan level terendah yang kurang memberikan perhatian terhadap pengembangan kuda Sandelwood akibat orientasi kebijakan yang terfokus untuk memenuhi kebutuhan daging dan susu, sehingga dikonsentrasikan kepada ternak Sapi dan Kerbau. Kondisi tersebut apabila tidak ditangani dikhawatirkan dapat mengakibatkan terjadinya pengurasan populasi, mengancam keberlanjutan, mengurangi nilai budaya, sekaligus mengubah pandangan tradisi budaya lokal sebagai sebuah beban sosial dalam melestarikannya.

Secara khusus penelitian yang berkaitan dengan pengembangan kuda Sandelwood di Indonesia masih sangat terbatas. Setyobudi et al. (2009) menyatakan bahwa penelitian ternak kuda belum banyak dilakukan dan kurang mendapatkan perhatian, dibuktikan dari terbatasnya publikasi dan diskusi pengembangannya. Randu (2017c) dalam penelitian di Kabupaten SBD menemukan bahwa status keberlanjutan dimensi ekologi pengembangan kuda Pasola berada pada kategori kurang berkelanjutan $(42,74 \%)$ sedangkan sosial budaya cukup berkelanjutan (51,61\%). Peningkatan status keberlanjutan dapat diupayakan melalui kerja sama pemerintah daerah dan peternak kuda melalui penyediaan bibit, pakan, dan air; pemanfaatan limbah pertanian; peningkatan manajemen usaha; serta peningkatan pengetahuan terhadap nilai gizi daging dan susu kuda. Takaendengan (2011) dalam penelitian di Provinsi Sulawesi Utara menemukan bahwa kondisi sosio-ekonomi peternak kuda didominasi pendidikan formal setara SLTA; pengetahuan rendah-sedang dalam bidang pemuliaan, pakan, manajemen, dan kelembagaan; jumlah kuda peliharaan yang terbatas; pengalaman beternak yang lama; dukungan pemerintah daerah yang rendah dalam penyediaan infrastruktur dan peraturan yang mendukung industri perkudaan; minimnya peran lembaga akademik dalam menciptakan sumber daya manusia pada industri ternak kuda; serta kajian yang masih terbatas bagi pengembangan ternak kuda.

Kuda Sandelwood yang dikembangkan di wilayah Pasola Kabupaten SBD pada masa mendatang perlu didukung berbagai data dan informasi terkait karakteristik peternak dan kondisi eksisting. Karakteristik peternak memiliki peran penting dalam meningkatkan jumlah populasi dan skala usaha pengembangan kuda Sandelwood, sedangkan kondisi eksisting diperlukan sebagai upaya mengoptimalkan nilai tambah dan efisiensi dalam pengelolaan kuda Sandelwood yang berkelanjutan. Penelitian bertujuan untuk: (1) mengetahui karakteristik peternak kuda Sandelwood di wilayah Pasola Kabupaten SBD, (2) mengetahui kondisi eksisting aktivitas peternak dalam pengembangan kuda Sandelwood di wilayah Pasola Kabupaten SBD.

\section{MATERI DAN METODE}

Penelitian dilaksanakan di Desa Pero Batang, Desa Ate Dalo (Kecamatan Kodi), Desa Waikaninyo, Desa Umbu Ngedo (Kecamatan Kodi Bangedo), dan Desa Waiha, Desa Wainyapu (Kecamatan Kodi Balaghar) pada bulan April-Juli 2016. Penentuan Desa sampel dilakukan secara sengaja (purposive sampling) dengan mempertimbangkan bahwa tradisi Pasola di Kabupaten SBD hanya dilaksanakan pada 6 Desa dan 3 wilayah Kecamatan bersangkutan.

Metode pengumpulan data dilakukan menggunakan teknik survey. Data yang dikumpulkan terdiri atas data primer dan data sekunder. Data primer diperoleh melalui wawancara mendalam (indepth interview) terhadap 79 responden peternak menggunakan kuesioner. Metode penentuan responden dilakukan secara purposive sampling dengan kriteria memiliki pengalaman beternak kuda Sandelwood minimal 3 (tiga) tahun terakhir, memanfaatkan kuda Sandelwood dalam urusan sosial budaya minimal 2 (dua) tahun terakhir, mempunyai motivasi mengembangkan kuda Sandelwood, dan pada saat penelitian dilakukan sedang memelihara kuda Sandelwood.

Data sekunder diperoleh dari berbagai sumber dan instansi terkait, berupa koleksi dokumen yang relevan dengan tujuan penelitian. Analisis data dilakukan secara statistik deskriptif untuk diketahui distribusi frekuensi jawaban peternak kuda Sandelwood dari kuesioner yang diberikan. Variabel karakteristik 
peternak terdiri atas umur, jenis kelamin, pendidikan formal, pendidikan non formal, mata pencaharian, jumlah tanggungan keluarga, pengalaman beternak, jumlah kepemilikan ternak, dan tujuan pemeliharaan ternak. Variabel kondisi eksisting pengembangan kuda Sandelwood terdiri atas kondisi modal dan pemasaran, kondisi manajemen dan sumber daya manusia, kondisi infrastruktur dan teknologi, serta kondisi kelembagaan dan kebijakan.

\section{HASIL DAN PEMBAHASAN}

\section{Karakteristik Peternak Kuda Sandelwood}

Berdasarkan hasil wawancara terhadap peternak kuda Sandelwood diketahui bahwa umur peternak berkisar antara 23-67 tahun, dengan rata-rata 43,51 tahun. Peternak yang berada dalam umur produktif sebanyak 75 orang $(94,94 \%)$, dan non produktif sebanyak 4 orang $(5,06 \%)$. Rohaeni et al. (2014) menyatakan bahwa umur produktif berkisar 15-64 tahun, sedangkan umur non produktif berada di bawah 15 tahun dan di atas 64 tahun. Peternak dalam usia produktif memiliki potensi mengembangkan diri dan menjalankan aktivitas usaha tani. Apabila ditinjau dari kategori umur, diketahui bahwa peternak kuda Sandelwood tergolong produktif sehingga memiliki kemampuan fisik dan psikologi untuk meningkatkan produktivitas ternak kuda, mempertahankan keberlanjutan, serta meminimalisir risiko pengembangan kuda Sandelwood (Tabel 1).

Hasil penelitian menunjukkan bahwa distribusi peternak berdasarkan jenis kelamin didominasi lakilaki $(89,87 \%)$ dan perempuan $(10,13 \%)$. Kondisi tersebut menggambarkan bahwa pemeliharaan kuda Sandelwood di wilayah Pasola Kabupaten SBD dominan dilakukan laki-laki. Hasil penelitian serupa dikemukakan Takaendengan (2011) yang melaporkan dominasi laki-laki (96\%) sebagai peternak kuda di Provinsi Sulawesi Utara. Tingginya kontribusi laki-laki dalam pemeliharaan kuda Sandelwood di wilayah Pasola Kabupaten SBD selain berkaitan dengan peran sebagai kepala rumah tangga, juga memiliki hubungan secara sosial budaya. Kuda diasosiasikan sebagai simbol maskulinitas yang tanggung jawab pemeliharaannya diserahkan kepada laki-laki. Pengembangan kuda Sandelwood yang dilakukan perempuan umumnya hanya meneruskan usaha keluarga, warisan suami yang meninggal, ataupun diperoleh dari urusan adat-istiadat (mahar).

Rataan pendidikan formal peternak kuda Sandelwood berdasarkan hasil analisis diketahui sangat rendah $(35,44 \%)$ dan merupakan tamatan Sekolah Dasar, sedangkan yang menyelesaikan pendidikan Sekolah Menengah Atas hanya 12,66\% (Tabel 1). Penelitian yang dilakukan Dongga (2014b) di Kabupaten Sumba Timur serta Turangan (2017) di Kabupaten Minahasa juga menunjukkan hasil yang relatif sama, dimana sebagian besar peternak kuda memiliki tingkat pendidikan setara Sekolah Dasar (SD). Rendahnya tingkat pendidikan peternak merupakan penghambat dalam proses adopsi dan inovasi teknologi peternakan, sehingga peternak cenderung untuk terus menerapkan manajemen pengelolaan usaha kuda Sandelwood secara konvensional dan turun-temurun.

Pendidikan non formal merupakan upaya peningkatan kualitas peternak dalam pengembangan usaha tani, terutama untuk memperbaiki pengetahuan, sikap, dan keterampilan sehingga memiliki dampak positif terhadap diri dan keluarga. Pendidikan non formal meliputi pelatihan, kursus, dan penyuluhan. Hasil penelitian menunjukkan bahwa $68,35 \%$ peternak kuda Sandelwood di wilayah Pasola Kabupaten SBD tidak pernah mengikuti pendidikan non formal, dan hanya $31,65 \%$ yang pernah mengikuti pendidikan non formal melalui pelatihan pembuatan silase dan bokashi (Tabel 1). Kondisi tersebut menunjukkan bahwa tingkat pengenalan dan transfer teknologi dalam aktivitas pengembangan kuda Sandelwood mengalami hambatan akibat tidak adanya pelatihan terkait manajemen produksi maupun reproduksi, usaha, serta pemasaran kuda Sandelwood. Hambatan lainnya dipengaruhi oleh terbatasnya jumlah kelompok peternak yang dibentuk sebagai wadah untuk memperoleh informasi teknologi peternakan. Tomatala (2008) menyatakan bahwa melalui pendidikan non formal diharapkan mampu mengubah cara berpikir peternak melalui penguasaan pengetahuan praktis dalam bidang peternakan yang kelak dimanfaatkan bagi peningkatan usaha.

Peternak kuda Sandelwood di wilayah Pasola Kabupaten SBD diketahui memiliki mata pencaharian utama yang cukup bervariasi, diantaranya: petani, peternak, ojek, tukang bangunan, dan pegawai kontrak daerah (Honorer). Namun demikian, petani merupakan mata pencaharian yang dominan dijalani $86,07 \%$ peternak kuda Sandelwood (Tabel 1). Hasil tersebut lebih tinggi dari penelitian Dongga (2013a) di Kabupaten Sumba Timur yang menyatakan bahwa sebanyak $62,5 \%$ peternak kuda memiliki mata pencaharian sebagai petani, relatif sesuai dengan penelitian Riadi et al. (2014) di Kabupaten Banyumas yang menyatakan bahwa $88,4 \%$ peternak sapi memiliki mata pencaharian pokok sebagai petani/buruh, dan lebih tinggi dibandingkan penelitian Takaendengan (2011) yang menyatakan bahwa 75,5\% peternak kuda di Sulawesi Utara memilki mata pencaharian utama sebagai petani. Kondisi tersebut memberikan gambaran bahwa usaha pengembangan kuda Sandelwood masih merupakan usaha sampingan dan belum menjadi usaha pokok yang ditekuni para peternak di wilayah Pasola Kabupaten SBD.

Jumlah tanggungan keluarga adalah banyaknya orang yang berada di dalam manajemen rumah tangga selain kepala keluarga. Jumlah tanggungan keluarga memiliki keterkaitan dengan alokasi biaya untuk konsumsi rumah tangga dan turut mempengaruhi besaran biaya untuk mengembangkan kuda Sandelwood. Pada sisi yang lain, jumlah tanggungan keluarga sesungguhnya merupakan potensi tenaga kerja dalam mendukung pengembangan kuda Sandelwood. 
Berdasarkan hasil penelitian, diketahui jumlah tanggungan keluarga peternak kuda Sandelwood di wilayah Pasola Kabupaten SBD berkisar antara 1-10 orang. Peternak kuda Sandelwood sebagian besar mempunyai tanggungan keluarga 4-7 orang $(45,57 \%)$. Hasil penelitian tersebut relatif sama dengan Rohaeni et al. (2014) di Kabupaten Tanah Laut yang menemukan rataan jumlah tanggungan keluarga peternak berada dalam kategori sedang yaitu 3-4 orang $(60,29 \%)$, dan
4-7 orang $(59,58 \%)$, namun berbeda dengan hasil penelitian Dongga (2014b) di Kabupaten Sumba Timur yang berada pada kisaran 5-10 orang $(53,13 \%), 1-4$ orang $(38,54 \%)$, dan di atas 10 orang $(8,33 \%)$. Febrina dan Liana (2008) menyatakan bahwa jumlah anggota keluarga mempengaruhi kebutuhan ekonomi walaupun di satu sisi dapat digunakan untuk meringankan usaha peternakan.

Tabel 1. Karakteristik peternak kuda sandelwood di wilayah pasola Kabupaten SBD

\begin{tabular}{|c|c|c|}
\hline Karakteristik Peternak & Jumlah (Orang) & Persentase (\%) \\
\hline \multicolumn{3}{|l|}{ Umur } \\
\hline $15-24$ tahun & 1 & 1,27 \\
\hline $25-34$ tahun & 13 & 16,46 \\
\hline $35-44$ tahun & 29 & 36,71 \\
\hline $45-54$ tahun & 23 & 29,11 \\
\hline $55-64$ tahun & 9 & 11,39 \\
\hline$>65$ tahun & 4 & 5,06 \\
\hline \multicolumn{3}{|l|}{ Jenis Kelamin } \\
\hline Laki - laki & 71 & 89,87 \\
\hline Perempuan & 8 & 10,13 \\
\hline \multicolumn{3}{|l|}{ Pendidikan Formal } \\
\hline Tidak sekolah & 14 & 17,72 \\
\hline Tidak tamat SD & 15 & 18,98 \\
\hline Tamat SD & 28 & 35,44 \\
\hline Tidak tamat SMP & 1 & 1,27 \\
\hline Tamat SMP & 8 & 10,13 \\
\hline Tidak tamat SMA & 3 & 3,80 \\
\hline Tamat SMA & 10 & 12,66 \\
\hline \multicolumn{3}{|l|}{ Pendidikan Non Formal } \\
\hline Tidak pernah mengikuti & 54 & 68,35 \\
\hline Pernah mengikuti & 25 & 31,65 \\
\hline \multicolumn{3}{|l|}{ Mata Pencaharian Utama } \\
\hline Petani & 68 & 86,07 \\
\hline Peternak & 8 & 10,12 \\
\hline Ojek & 1 & 1,27 \\
\hline Tukang & 1 & 1,27 \\
\hline Tenaga kontrak daerah (Honor) & 1 & 1,27 \\
\hline \multicolumn{3}{|l|}{ Jumlah Tanggungan Keluarga } \\
\hline $0-3$ orang & 28 & 35,44 \\
\hline $4-7$ orang & 36 & 45,57 \\
\hline$>8$ orang & 15 & 18,99 \\
\hline \multicolumn{3}{|l|}{ Pengalaman Beternak } \\
\hline $1-10$ tahun & 11 & 13,92 \\
\hline $11-20$ tahun & 26 & 32,91 \\
\hline $21-30$ tahun & 28 & 35,44 \\
\hline $31-40$ tahun & 9 & 11,39 \\
\hline $41-50$ tahun & 5 & 6,33 \\
\hline \multicolumn{3}{|l|}{ Jumlah Kepemilikan Ternak } \\
\hline$<5$ ekor & 76 & 96,20 \\
\hline $5-6$ ekor & 2 & 2,53 \\
\hline$>6$ ekor & 1 & 1,27 \\
\hline \multicolumn{3}{|l|}{ Tujuan Pemeliharaan } \\
\hline Hobi & 9 & 11,39 \\
\hline Persiapan pacuan kuda & 15 & 18,99 \\
\hline Sarana transportasi & 1 & 1,27 \\
\hline Kebutuhan adat - istiadat & 43 & 54,43 \\
\hline Kebutuhan jual beli & 11 & 13,92 \\
\hline
\end{tabular}

Sumber: Data Primer Diolah. 2016 
Berdasarkan hasil penelitian diketahui rata-rata pengalaman beternak kuda kuda Sandelwood di wilayah Pasola Kabupaten SBD adalah 23 tahun, dengan kisaran 21-30 tahun (35,44\%). Kondisi tersebut memberikan gambaran bahwa pengembangan kuda Sandelwood telah menjadi bagian penting dari aktivitas pertanian masyarakat. Peternak yang memelihara kuda Sandelwood dalam waktu lama dapat dikategorikan mempunyai banyak pengalaman, meskipun terdapat berbagai faktor lain yang turut mempengaruhinya. Mastuti dan Hidayat (2008) menyatakan bahwa pengalaman beternak yang lama diharapkan meningkatkan pengetahuan peternak, dan pada gilirannya mampu meningkatkan keterampilan menjalankan usaha peternakan.

Jumlah kepemilikan ternak adalah jumlah kuda Sandelwood yang dimiliki dan dipelihara secara keseluruhan oleh peternak, serta diukur dalam satuan ekor. Besar kecilnya jumlah kuda Sandelwood yang dimiliki merupakan salah satu indikator keberhasilan pengemba ngan ternak kuda di wilayah Pasola. Hasil penelitian menunjukkan bahwa jumlah kepemilikan kuda Sandelwood bervariasi 1-7 ekor, dengan rata-rata kepemilikan 2 ekor. Peternak dominan memiliki kuda Sandelwood di bawah 5 ekor $(96,20 \%)$, sebagian kecil memiliki 5-6 ekor $(2,53 \%)$, dan sisanya memiliki 7 ekor $(1,27 \%)$. Kuda Sandelwood dengan kepemilikan lebih dari 7 ekor per peternak tidak ditemui dalam penelitian (Tabel 1). Hal tersebut mengindikasikan bahwa pengelolaan usaha kuda Sandelwood masih dilakukan dalam skala kecil dan bersifat sambilan sehingga membutuhkan peningkatan populasi dan produktivitas dalam rangka meningkatkan kontribusi pendapatan yang disumbangkan dari usaha ternak kuda. Paturochmah (2005) menyatakan bahwa terdapat hubungan antara skala kepemilikan ternak dan pendapatan. Ternak yang dipelihara dalam jumlah banyak akan meningkatkan pendapatan karena terjadi efisiensi penggunaan sarana dan biaya produksi, walaupun masih ditemui kelemahan utama yang berkaitan dengan rendahnya kemampuan peternak atau produsen dalam memanfaatkan sumber daya akibat pengadaan pakan, bibit, transportasi, maupun pemeliharaan dilakukan terbatas.

Pemeliharaan kuda Sandelwood di wilayah Pasola Kabupaten SBD memiliki tujuan ekonomi dan non ekonomi. Tujuan ekonomi berkaitan dengan keinginan peternak untuk mendapatkan manfaat usaha berupa tabungan keluarga yang dapat digunakan sewaktu-waktu, sedangkan tujuan non ekonomi berkaitan dengan keinginan peternak untuk menyalurkan hobi, persiapan pacuan kuda, meningkatkan status sosial, sarana transportasi, serta memenuhi kebutuhan adat-istiadat. Hasil penelitian menunjukkan bahwa kuda Sandelwood dominan dipelihara untuk tujuan non ekonomi, yaitu memenuhi kebutuhan adat istiadat $(54,43 \%)$, dan hanya $13,92 \%$ peternak memelihara kuda Sandelwood untuk tujuan ekonomi, yaitu kebutuhan jual beli (Tabel 1). Hasil tersebut berbeda dengan penelitian yang dilaporkan
Takaendengan (2011) bahwa sebagian besar pemeliharaan kuda di Provinsi Sulawesi Utara bertujuan sebagai sumber pendapatan utama. Perbedaan tujuan pemeliharaan diduga berkaitan dengan pemanfaatan kuda yang dominan di Provinsi Sulawesi Utara untuk menarik bendi/delman dan pacuan, sedangkan kuda Sandelwood di wilayah Pasola Kabupaten SBD lebih banyak dimanfaatkan untuk urusan perkawinan, kematian, dan Pasola. Hal tersebut didukung oleh Eha (2004) dan Lidjang (2004) yang menyatakan bahwa kuda memiliki nilai tertinggi dalam mitologi Sumba karena digunakan sebagai pelayan selama manusia hidup (fungsi pengangkutan barang dan jasa) dan kemudian dipotong sebagai hewan tunggangan menuju alam baka. Ide utama masyarakat memelihara kuda adalah memperoleh material yang dapat digunakan untuk berbagai ritual kebudayaan.

\section{Kondisi Eksisting Pengembangan Kuda Sandelwood}

Aktivitas pengembangan Kuda Sandelwood yang dilakukan oleh peternak di wilayah Pasola Kabupaten SBD saat ini secara internal dipengaruhi oleh kondisi modal dan pemasaran, manajemen dan sumber daya manusia, dan secara eksternal dipengaruhi oleh dukungan infrastruktur dan teknologi, serta kelembagaan dan kebijakan. Modal dan pemasaran meliputi sumber dan dukungan modal; sistem pemasaran; serta jangka waktu pemeliharaan kuda Sandelwood sebelum dipasarkan. Manajemen dan sumber daya manusia mencakup sistem pemeliharaan; sumber dan ketersediaan bibit; manajemen pakan hijauan dan konsentrat; pengetahuan reproduksi dan produk utama; serta frekuensi konsumsi produk utama kuda Sandelwood. Infrastruktur dan teknologi terdiri dari ketersediaan fasilitas pendukung; penerapan teknologi kesehatan hewan, reproduksi, pakan dan limbah. Kelembagaan dan kebijakan meliputi intensitas penyuluhan atau demonstrasi plot (demplot); jumlah tenaga penyuluh dan ketersediaan lembaga usaha tani; serta kebijakan politik dan anggaran untuk pengembangan kuda Sandelwood.

\section{Kondisi Modal dan Pemasaran}

Hasil penelitian menunjukkan bahwa kuda Sandelwood yang dikembangkan peternak sebagian besar menggunakan modal pribadi $(43,04 \%)$, demikian pula dukungan modal pemerintah umumnya hanya diberikan dalam bentuk bibit kuda Sandelwood yang jumlahnya terbatas dan penyebaran tidak merata $(34,18 \%)$. Sistem pemasaran kuda Sandelwood umumnya dilakukan melalui pedagang perantara (pengumpul) dalam wilayah Desa $(41,77 \%)$. Sistem pemasaran yang demikian merugikan para peternak akibat terbatasnya informasi dan ketidakmampuan mempengaruhi harga jual walaupun tersedia peluang atau potensi yang sangat besar dari sisi pemasaran akibat pemanfaatan kuda Sandelwood yang wajib digunakan dalam setiap upacara perkawinan, kematian, dan pasola. Besaran harga jual kuda Sandelwood saat 
dilakukan penelitian, yaitu: anak Rp.3.000.000Rp.4.500.000; muda Rp.4.500.000-Rp.5.500.000; dan dewasa Rp.5.500.000-Rp.7.500.000.

Jangka waktu pemeliharaan kuda Sandelwood di wilayah Pasola umumnya bervariasi dan tidak menentu karena lebih banyak disesuaikan dengan kebutuhan mendesak peternak yaitu perkawinan dan kematian $(56,96 \%)$. Berbagai hal tersebut memberikan gambaran bahwa kondisi modal dan pemasaran di tingkat peternak masih merupakan pembatas dalam mendukung pengembangan kuda Sandelwood di wilayah Pasola Kabupaten SBD. Budiraharjo (2003) menyatakan bahwa usaha peternakan rakyat seringkali memiliki kelemahan berkaitan dengan pengambilan keputusan pembelian, penjualan dan penentuan harga jual yang dilakukan tanpa pertimbangan matang. Dewanta, 2004 disitasi Riadi dkk. (2014) menyatakan bahwa tinggi rendahnya jumlah modal yang dimiliki peternak akan sangat menentukan jumlah ternak yang dipelihara.

\section{Kondisi Manajemen dan SDM}

Hasil penelitian menunjukkan bahwa sistem manajemen pemeliharaan kuda Sandelwood sebagian besar dilakukan secara semi intensif yaitu ternak dilepas pada pagi hari di sekitar tempat tinggal peternak, dan sore harinya dikandangkan kembali (50,63\%). Sumber bibit kuda Sandelwood yang digunakan peternak untuk kegiatan budidaya dominan bersumber dari hasil pemberian belis (mahar) dalam urusan perkawinan $(35,44 \%)$. Ketersediaan bibit kuda Sandelwood yang berkualitas sangat terbatas di wilayah penelitian (37,97\%). Peternak umumnya kurang memperhatikan aspek manajemen pakan, dibuktikan dari rendahnya perhatian terhadap ketersediaan hijauan maupun konsentrat (70,89\%).

Peternak umumnya memberikan hijauan yang bersumber dari lahan maupun padang dengan ketersediaan yang tidak kontinyu, sedangkan konsentrat secara khusus diberikan hanya untuk kuda Sandelwood yang dipersiapkan dalam pacuan dan Pasola (Kuda Nyale dan Halato). Hijauan dan konsentrat diberikan peternak dengan frekuensi yang tidak menentu $(68,35 \%)$. Peternak juga sama sekali belum memanfaatkan limbah ternak kuda (feces) untuk menunjang kegiatan pertanian $(75,95 \%)$. Peternak memiliki pengetahuan yang baik menyangkut reproduksi ternak kuda $(41,77 \%)$, namun dari sisi penerapan manajemen perkawinan belum dilakukan secara teratur $(67,09 \%)$ karena sistem perkawinan yang dominan dilakukan adalah alamiah. Petugas IB yang secara khusus menangani perkawinan kuda Sandelwood tidak tersedia. Peternak di lokasi penelitian juga kurang mengetahui manfaat produk daging $(39,24 \%)$ dan susu kuda Sandelwood (59,49\%). Kondisi tersebut dibuktikan secara faktual dimana $54,43 \%$ peternak tidak pernah mengkonsumsi daging kuda Sandelwood dan 72,15\% peternak tidak pernah mengkonsumsi susu kuda Sandelwood.
Terbatasnya pengetahuan dan frekuensi konsumsi produk ternak kuda (daging dan susu) memberikan gambaran rendahnya dukungan manajemen dan sumber daya manusia dalam pengembangan kuda Sandelwood di wilayah Pasola Kabupaten SBD. Nur dkk. (2000) menyatakan bahwa pengembangan sumber daya manusia merupakan fokus yang sangat penting diperhatikan dalam pengembangan peternakan rakyat. Hal tersebut disebabkan karena kerugian usaha peternakan seringkali disebabkan oleh tatalaksana atau manajemen yang belum dilakukan secara baik (Suherman, 2008).

\section{Kondisi Infrastruktur dan Teknologi}

Kondisi infrastruktur pengembangan kuda Sandelwood meliputi tersedianya pasar hewan yang telah berfungsi dengan baik dan sangat mendukung dalam kegiatan pemasaran $(49,37 \%)$ maupun puskeswan yang tersedia dan berfungsi dalam mendukung pelayanan kesehatan hewan (39,24\%). Kecamatan Kodi, Kodi Bangedo, dan Kodi Balaghar yang menjadi lokasi penelitian mempunyai masingmasing 1 buah pasar hewan, dan ditunjang oleh pasar induk yang terletak di Ibu kota Kabupaten SBD. Transaksi penjualan hewan di pasar dilakukan setiap minggu dengan waktu (hari) penjualan bervariasi antara kecamatan, sedangkan pasar induk beroperasi setiap hari. Puskeswan tersedia di setiap wilayah kecamatan penelitian untuk mempercepat penanganan masalah kesehatan hewan di tingkat peternak. Teknologi kesehatan hewan berupa kegiatan vaksinasi selalu dilakukan secara terprogram setiap tahunnya oleh penyuluh $(54,43 \%)$, namun di tingkat peternak pemberian vitamin untuk menunjang kesehatan kuda Sandelwood sama sekali tidak pernah dilakukan $(67,09 \%)$.

Hasil penelitian juga diketahui bahwa peternak belum sepenuhnya menerapkan teknologi peternakan dalam usaha pemeliharaan kuda Sandelwood, khususnya teknologi reproduksi $(67,09 \%)$, teknologi pakan (70,89\%), dan teknologi pengolahan limbah $(63,29 \%)$. Kondisi infrastruktur yang berkaitan dengan pengembangan kuda Sandelwood walaupun cukup tersedia dan menunjang, namun peranan teknologi di tingkat peternak masih merupakan ancaman. Tomatala (2008) menyatakan bahwa pengembangan peternakan memerlukan dukungan infrastruktur berupa: pasar ternak, puskeswan, rumah potong hewan, dan sarana transportasi. Gumbira (2001) menyatakan bahwa teknologi merupakan sarana peningkatan produktivitas, pencapaian efektivitas, dan penciptaan efisiensi usaha. Teknologi peternakan di Indonesia saat ini sebagian besar masih menempatkan peternak sebagai penerima, dan bukan merupakan bagian dari pengguna (Hasnudi et al., 2004).

\section{Kondisi Kelembagaan dan Kebijakan}

Aspek kelembagaan dan kebijakan yang perlu mendapatkan perhatian dalam pengembangan kuda Sandelwood di wilayah Pasola Kabupaten SBD adalah 
rendahnya intensitas penyuluhan ataupun demplot yang dilakukan petugas teknis (penyuluh) peternakan $(64,56 \%)$. Hal tersebut disebabkan karena jumlah tenaga penyuluh peternakan sangat terbatas (1 orang menangani satu wilayah kecamatan sehingga tidak sebanding dengan cakupan luas wilayah pelayanan (50,63\%). Kondisi tersebut mengakibatkan interaksi penyuluh dan peternak dalam kegiatan penyuluhan dan demplot hanya terjadi $2-3$ kali setiap tahunnya bertepatan dengan saat dilakukan kegiatan vaksinasi dan pengobatan massal ternak kuda, ataupun pada saat pemberian bantuan bibit kuda Sandelwood oleh pemerintah daerah. Pada sisi lain, kelembagaan usaha tani dalam bentuk kelompok peternak sangat terbatas $(62,03 \%)$ sehingga tidak mampu mengakomodir keberadaan seluruh peternak kuda Sandelwood untuk aktif dalam kegiatan penyuluhan/demplot $(53,16 \%)$. Kelembagaan swasta yang mendukung pengembangan kuda Sandelwood dalam bentuk perusahaan peternakan tidak tersedia di Kabupaten SBD.

Lembaga usaha tani (kelompok peternak) kuda Sandelwood di wilayah Pasola seringkali dibentuk hanya sebagai prasyarat memperoleh bantuan, walaupun secara teknis kurang mampu meningkatkan partisipasi dan keaktifan anggota. Penyuluh peternakan mempunyai keterbatasan dalam meningkatkan keaktifan peternak dan kelompok peternak karena kurang tersedianya program kerja yang dirancang dengan melibatkan peternak. Ketersediaan kelembagaan koperasi unit desa (KUD) maupun badan usaha milik desa (BUMDES) sebagai lokomotif pembangunan ekonomi lokal di tingkat peternak juga belum dikembangkan secara optimal. Aspek kebijakan pada level Provinsi (55,70\%), Kabupaten (65,82\%), dan Kecamatan/ Desa (51,90\%) masih kurang memberikan perhatian terhadap pengembangan kuda Sandelwood. Kebijakan anggaran pada level Provinsi dan Kabupaten (64,56\%) diarahkan untuk pengembangan ternak sapi, kerbau, kambing, dan babi. Kondisi tersebut menunjukkan bahwa dukungan kelembagaan dan peran kebijakan kurang menunjang upaya pengembangan kuda Sandelwood di wilayah Pasola Kabupaten SBD. Abdullah (2008) dan Philips et al. (2011) menyatakan bahwa peningkatan produktivitas ternak maupun peternak di wilayah pedesaan dapat dioptimalkan melalui pendekatan kelompok tani. Keberadaan kelompok tani merupakan komponen penunjang aktivitas pembinaan oleh lembaga terkait disamping wahana peningkatan pengetahuan dan keterampilan anggota kelompok tani melalui penyuluhan, pelatihan, dan demplot. Pemerintah di era otonomi daerah perlu menghasilkan kebijakan yang mempertimbangkan kesesuaian komoditas, sehingga pada akhirnya dapat meningkatkan produktivitas dan efisiensi dalam kerangka mendukung kreativitas maupun daya kerja peternak (Paggasa, 2008). Optimalisasi potensi pengembangan kuda Sandelwood di wilayah Pasola saat ini perlu dilakukan pada setiap level pemerintahan melalui dukungan kebijakan politik maupun anggaran, perubahan cara pandang terhadap nilai ekonomi kuda Sandelwood, serta dorongan terhadap konsumsi daging dan susu kuda Sandelwood di Kabupaten SBD.

\section{SIMPULAN}

Berdasarkan hasil dan pembahasan, dapat disimpulkan bahwa pengembangan kuda Sandelwood di wilayah Pasola Kabupaten SBD masih merupakan usaha sampingan yang diarahkan untuk tujuan non ekonomi yaitu memenuhi kebutuhan adat-istiadat. Karakteristik peternak didominasi laki-laki yang berusia produktif dengan pengalaman beternak yang lama, namun mempunyai jumlah kepemilikan kuda Sandelwood yang terbatas, tingkat pendidikan yang rendah, dan pelatihan teknis peternakan yang terbatas. Kondisi eksisting aktivitas pengembangan kuda Sandelwood dipengaruhi oleh terbatasnya modal di tingkat peternak serta ketidakmampuan mempengaruhi harga jual ternak kuda. Tatalaksana pemeliharaan kuda Sandelwood masih dilakukan secara tradisional, kurang memperhatikan aspek manajemen pakan dan pemanfaatan produk daging maupun susu, serta belum menerapkan teknologi reproduksi, pakan, dan limbah. Kelembagaan pengembangan kuda Sandelwood masih sangat terbatas dan kurang didukung oleh jumlah dan aktivitas tenaga teknis penyuluh peternakan.

\section{DAFTAR PUSTAKA}

Abdullah, A. 2008. Identifikasi Kelas Kemampuan Kelompok Tani Ternak di Kecamatan Herlang Kabupaten Bulukumba. Jurnal Ilmu Ternak 8(1): $77-82$.

Adams, R. 2004. The Megalithic Tradition of West Sumba. Simon Fraser University. Canada.

Adinata, K. I., A. I. Sari., dan E. T. Rahayu. 2012. Strategi Pengembangan Usaha Sapi Potong di Kecamatan Mojolaban Kabupaten Sukoharjo. Tropical Animal Husbandry 1(1): 24-32.

Badan Pusat Statistik Kabupaten SBD. 2017. Sumba Barat dalam Angka. Katalog BPS: 1102001.5317.

Badan Pusat Statistik Provinsi NTT. 2017. Nusa Tenggara Timur dalam Angka. Katalog BPS: 1102001.53 .

Budiraharjo, K. 2003. Beberapa Faktor yang Mempengaruhi Petani Peternak dalam Pengambilan Keputusan Manajemen Usaha Ternak Kambing di Kota Semarang. Tesis. Program Studi Magister Ilmu Ternak. Universitas Diponegoro. Semarang.

Detha, A., Sudarwanto, M., Latif, H., dan F. U. Datta. 2013. Identifikasi Kandungan Protein dan Potensi Pemanfaatan Susu Kuda Sumba di Pulau Sumba. Jurnal Flobamora Pemerintah Provinsi Nusa Tenggara Timur 8(4): 250-259

Disnak Kabupaten SBD. 2016. Pengeluaran Ternak dari Kabupaten Sumba Barat Daya Tahun 20112015. Dinas Peternakan Kabupaten Sumba Barat Daya. Weetabula. 
Ditjennak. 2014. Keputusan Menteri Pertanian Republik Indonesia Nomor 426/Kpts/SR.120/3/2014 Tentang Penetapan Rumpun Kuda Sandel. http://bibit.ditjennak.pertanian.go. $\mathrm{id} /$ sites/default/files/Kuda\%20Sandel.pdf. Diakses tanggal 22 Oktober 2015.

Djawa, A. R. 2014. Ritual Marapu di Masyarakat Sumba Timur. Avatara, e-journal Pendidikan Sejarah 2(1): 71-85.

Dongga, R. E. D. 2013a. Adopsi Teknologi Pengendalian Penyakit Surra oleh Peternak Kuda di Kabupaten Sumba Timur. Nusa Tenggara Timur. Tesis. Program Studi Ilmu Peternakan. Program Pasca Sarjana. Universitas Udayana. Denpasar.

Dongga, R. E. D. 2013b. Adopsi Teknologi Pengendalian Penyakit Surra oleh Peternak Kuda di Kabupaten Sumba Timur, Nusa Tenggara Timur. Buletin Veteriner Udayana 6(1): 49-57.

Eha, E. B. 2004. Analisis Pergeseran Fungsi Sosial Kerbau di Sumba Timur. Tesis. Program Magister Studi Pembangunan. Universitas Kristen Satya Wacana. Salatiga.

Febrina, D., M. Liana. 2008. Pemanfaatan Limbah Pertanian Sebagai Pakan Ruminansia pada Peternak Rakyat di Kecamatan Rengat Barat Kabupaten Indragiri Hulu. Jurnal Peternakan 5(1): 28-37.

Gumbira, S., dan A. H. Intan. 2001. Manajemen Agribsnis. PT. Ghalia Indonesia. Jakarta.

Hasnudi, I. Sembiring., dan S. Umar. 2004. Pokokpokok Pemikiran Bidang Peternakan. Jurusan Peternakan. Fakultas Pertanian. Universitas Sumatera Utara.

Lidjang, I. K., O. T. Lailogo., dan Y. Ngongo. 2004. Kelayakan Sosial Budaya Inovasi Teknologi Pertanian/ Peternakan (Kasus Masyarakat Sumba Timur). Prosiding. Seminar Nasional Penelitian Ternak dan Usaha tani Lahan Kering: 348-368.

Mastuti, S., dan NN. Hidayat. 2008. Peranan Tenaga Kerja Perempuan dalam Usaha Ternak Sapi Perah di Kabupaten Kuningan. Animal Production 11(1): 40-47.

Nur, S., O. E. Djatmiko., dan S. Zubaidah. 2000. Pengembangan Industri Peternakan Rakyat Mandiri Melalui Penguatan Kelembagaan dan Pemberdayaan SDM. Animal Production 2(2): 60-68

Nurrochsyam, M. W. 2011. Tradisi Pasola Antara Kekerasan dan Kearifan Lokal. Text Book Kearifan Lokal di Tengah Modernisasi. Kementerian Kebudayaan dan Pariwisata Republik Indonesia. Jakarta.

Paggasa, Y. 2008. Potensi Pengembangan Sapi Potong Melalui Sistem Integrasi Sawit-Ternak di Kabupaten Kutai Timur Provinsi Kalimantan Timur. Tesis. Sekolah Pascasarjana. Institut Pertanian Bogor. Bogor.
Paturochmah, M. 2005. Hubungan Antara Tingkat Pendapatan Keluarga Peternak dengan Tingkat Konsumsi (Kasus di Koperasi Peternakan Bandung Selatan (KBPS) Pangalengan). Sosiohumaniora 7(3): 264-272.

Philips, J. C., F. Kolb., and C. Biknell. 2011. Strategic Analysis of The U. S. Quarter Horse Industry, Emphasizing California. Center for Food Marketing and Agribusiness Solutions California State Polytechnic University. Pomoma. California.

Putro, H. O., A. Setiadi., dan L. Kustiawan. 2014. Analisis Faktor-faktor yang Mempengaruhi Pengembangan Usaha Ternak Sapi Jawa Brebes (JABRES) di Kabupaten Brebes. Agromedia 32(1): 1-11.

Randu, M. D. S. 2017a. Strategi Pengembangan Ternak Kuda (Equus Caballus) Sebagai Sumber daya Lokal yang Bernilai Budaya di Kabupaten Sumba Barat Daya (Studi Kasus Kecamatan Kodi, Kodi Bangedo, dan Kodi Balaghar). Disertasi. Program Pascasarjana. Fakultas Peternakan. Universitas Brawijaya. Malang.

Randu, M. D. S., B. Hartono., B. A. Nugroho., and H. D. Utami. 2017b. Strategies in Developing Horse Breeding with Socio-Cultural Concept in The Regency of Sumba Barat Daya. International Journal of Economic Research 14(3): 363-373.

Randu, M. D. S., F. S. Suek., dan B. Hartono. 2017c. Status Keberlanjutan Dimensi Ekologi dan Sosial Budaya dalam Pengembangan Kuda Pasola di Kabupaten Sumba Barat Daya, Indonesia. Prosiding. Seminar Nasional Laboratorium Riset Terpadu Undana ke-2. Kupang: 77-83.

Riadi, S., S. Nur., dan K. Muatip. 2014. Faktor-Faktor yang Berpengaruh Terhadap Pendapatan Peternak Sapi di Kabupaten Banyumas. Jurnal Ilmiah Peternakan 2(1): 313-318.

Rohaeni, E. S., B. Hartono., Z. Fanani., and B. A. Nugroho. 2014. Sustainability of Cattle Farming using Analysis Approach of Structural Equation Modeling (A Study on Dry Land of Tanah Laut Regency, South Kalimantan, Indonesia). International Journal of Agronomy and Agricultural Research (IJAAR) 4(1): 8-21.

Setyobudi, A., Kustono., dan D. T. Widayati. 2009. Kinerja Reproduksi Ternak Kuda di Daerah Bantul, Daerah Istimewa Yogyakarta. Buletin Peternakan 33(3): 148-153.

Suherman, D. 2008. Evaluasi Penerapan Aspek Teknis Peternakan pada Usaha Peternakan Sapi Perah Sistem Individu dan Kelompok di Rejang Lebong. Jurnal Sain Peternakan Indonesia 3(1): 35-42.

Takaendengan, B. J. 2011. Potensi Genetik Kuda Lokal di Sulawesi Utara sebagai Sumber Bibit Kuda Indonesia. Disertasi. Sekolah Pascasarjana. Institut Pertanian Bogor. Bogor.

Tomatala, G. S. J. 2008. Kompetensi dan Keberdayaan Peternak dalam Pengembangan Usaha Peternakan Sapi Potong (Kasus Kabupaten Seram Bagian 
Barat Provinsi Maluku). Disertasi. Sekolah Pascasarjana. Institut Pertanian Bogor. Bogor.

Turangan, S. H. 2017. Penampilan Ternak Kuda Bendi di Kecamatan Tompaso Kabupaten Minahasa. Jurnal Zootek 37(1): 186-198. 